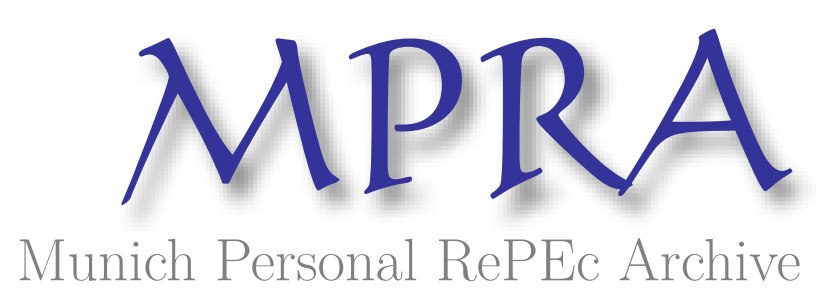

\title{
The Impact of Federal Deposit Insurance on Savings and Loan Failures
}

Cebula, Richard

Jacksonville University

12 March 1992

Online at https://mpra.ub.uni-muenchen.de/51540/

MPRA Paper No. 51540, posted 18 Nov 2013 21:04 UTC 


\title{
The Impact of Federal Deposit Insurance on Savings and Loan Failures
}

\author{
RICHARD J. CEBULA \\ Georgia Institute of Technology \\ Atlanta, Georgia
}

\section{Introduction}

The failure rate of federally insured Savings and Loans (S\&Ls) has reached proportions unprecedented since the Depression years prior to 1934. From the beginning of 1934 through the end of 1979 , the S\&L industry experienced comparatively few failures. Indeed, there were some 14 years during this period when not a single federally insured S\&L failed. In addition, there were some eight years over this time span that witnessed only one failed federally insured S\&L. Moreover, the number of failed federally insured S\&Ls reached double figures only three times over this entire period: 13 failures in 1941 and ten failures each in 1966 and 1970. Unfortunately, this record became blemished in the turbulent 1980s, when, according to Barth [2], some 525 federally insured S\&Ls failed.

Barth $[2,100-101]$ has argued that federal deposit insurance has encouraged the S\&Ls to take on additional risk and that in so doing federal deposit insurance has significantly contributed to the S\&L crisis. Barth $[2,100]$ charges that ". . . the very availability of such insurance enabled many inadequately capitalized savings and loans to engage in high-risk activities and to gamble for resurrection." Barth $[2,101]$ in fact alleges that ". . . the federal deposit insurance system was the unifying cause of the savings and loan disaster." In point of fact, Barth's arguments are in principle consistent with the arguments in many other studies $[4 ; 21 ; 23 ; 24 ; 33]$.

The purpose of this paper is to test empirically the hypothesis that federal deposit insurance has in fact acted significantly to raise the S\&L failure rate. Section II below develops the basic model. The model includes a variety of factors in addition to federal deposit insurance that are alleged by Barth [2] and others to have induced the S\&L failure problem. Section III provides the empirical analysis. The focus is on two measures of the S\&L failure rate: (1) the percentage of federally insured S\&Ls failing and (2) the number of federally insured S\&Ls failing. Given certain limitations on data availability, the time period studied runs from 1965-1989. In addition, of necessity, the basic data used in this study are annual. Conclusions are provided in section IV.

\section{The Basic Framework}

We begin the analysis by focusing on the potential impact of federal deposit insurance on $S \& L$ failures. The basic argument regarding federal deposit insurance and S\&L risk-taking incentives is actually a rather simple one. We begin by noting that, in point of fact, S\&Ls that are technically 
insolvent are oftentimes not closed (or merged with another institution) until their net worth is very significantly negative. For one thing, since it is often very difficult to assess the financial viability of various S\&L assets, especially real estate loans, an institution's insolvency is very difficult to determine. In addition, federal agencies, such as the (now-defunct) FSLIC, lack (lacked) the authority to immediately close S\&Ls judged to be insolvent. Indeed, the agency that chartered the $S \& L$ in question had to determine institutional insolvency before the FSLIC could take action. Clearly, given the existence of federal deposit insurance, S\&Ls near insolvency, becoming insolvent, expecting insolvency, or actually insolvent were provided a strong incentive to take greater risks in the pursuit of greater rates of return because they were, in effect, gambling for financial resurrection using the FSLIC's money and little if any of their own $[2 ; 4 ; 21 ; 23 ; 24 ; 33]$. As Kane $[24,219]$ so clearly points out, “. . . the FSLIC subsidizes its clients' risk-taking . . . . If the riskier undertakings proved unprofitable or resulted in a major loss, it was the federal insurer's funds, not the S\&L's own capital, that was at risk. In other words, federal (FSLIC) deposit insurance enabled and actually encouraged S\&Ls that desperately needed profits in order to avoid outright failure to take greater risks in the hope of a greater rate of return; if the venture failed, it was the FSLIC that would be liable for depositor losses, not the S\&L. Naturally, by inducing greater risk-taking activities on the part of S\&Ls, the federal deposit insurance exposed the S\&Ls to a greater probability of failure.

The ceiling on FSLIC insurance per account was $\$ 5,000$ from 1934 through 1949. The ceiling was then increased to $\$ 10,000$ in 1950 , where it remained through 1965 . It was again increased in 1966 to $\$ 15,000$, and then quickly raised again, effective in 1969 , to $\$ 20,000$. From 1974 through 1979 , it was set at $\$ 40,000$ (for non-government accounts). Finally, as of 1980, it was set at $\$ 100,000$. Table I provides the ceiling amount per account of FSLIC deposit insurance, expressed in 1982 dollars, for the years 1963 through 1989. The surges in the real FSLIC insurance ceiling clearly correspond to the surges in the nominal FSLIC insurance ceiling over this period. It is hypothesized here, based on the aforementioned literature and arguments, that the higher the ceiling level of FSLIC deposit insurance, the greater the incentive for S\&Ls to take risk and hence the greater the likelihood of S\&L failures.

A number of additional factors are also to be included in the analysis. For one thing, there was the 1981-1982 recession. This recession was quite severe as well as protracted $[2 ; 13 ; 15$; $18 ; 30]$. Among others, Barth [2] argues that this recession severely hurt the real estate industry, which was already at the time beleaguered by high mortgage rates. As a consequence, S\&L profitability and solvency were both severely compromised. Another potential factor in the S\&L crisis was the price of crude petroleum. The decline in crude oil prices from 1981 through 1985, combined with the marked price decline of crude petroleum between 1985 and 1986, appears to have hurt the real estate industry, especially in the Southwest $[20 ; 2]$, and to have thereby significantly reduced S\&L profitability and solvency. The empirical analysis in section III explicitly allows both for the 1981-1982 recession (with a binary variable) and for the price of crude petroleum.

Another set of factors relates to interest rates. Clearly, S\&L profitability is significantly tied to the cost of funds and to the mortgage rate, as well as the volatility thereof. As elaborated upon by Carron [12], Barth [2], and others, the higher the cost of funds to S\&Ls, the lower the S\&L profitability will tend to be and hence the higher the probability of S\&L failures will tend to be, ceteris paribus. This rudimentary argument of course parallels that applying to commercial banks [8]. On the other hand, it also follows from rudimentary micro-theory that, ceteris paribus, the higher the mortgage rate, the higher the $S \& L$ profitability and hence the lower the probability of $S \& L$ failures. In order to reflect the cost of funds, in section III we use the available annual data 
Table I. FSLIC Deposit Insurance Ceiling, 1982 Dollars

\begin{tabular}{cccc}
\hline Year & Insurance Ceiling per Account & Year & Insurance Ceiling per Account \\
\hline 1963 & $\$ 30864$ & 1977 & 59435 \\
1964 & 30395 & 1978 & 55402 \\
1965 & 29586 & 1979 & 50891 \\
1966 & 42857 & 1980 & 116686 \\
1967 & 41782 & 1981 & 106383 \\
1968 & 39788 & 1982 & 100000 \\
1969 & 50251 & 1983 & 96246 \\
1970 & 47619 & 1984 & 92851 \\
1971 & 45045 & 1985 & 90171 \\
1972 & 43011 & 1986 & 87796 \\
1973 & 40404 & 1987 & 84962 \\
1974 & 74074 & 1988 & 81367 \\
1975 & 67453 & 1989 & 79365 \\
1976 & 63391 & & \\
\hline
\end{tabular}

Jn the cost of funds to S\&Ls per se; to reflect mortgage rates, we use the available annual data on he S\&L mortgage portfolio yield. Naturally, since both of these variables are annual in nature, nterest rate levels attained in any year or the not fully describe either the maximum or minimum given year or other time period.

In any event, Barth [2, 38] argues that "In the late 1970s and early 1980s, interest rates ose to unexpectedly high levels and became extremely volatile." Barth [2, 38] further argues nd actions taken by the Board of Governor nd actions taken by the Board of Governors of the Federal Reserve System in the fall of 1979 olicy shift of October, 1979; this shift has been is of course the well-known Federal Reserve is stated by Evans [17,83], “. the Federal Reximined extensively $[1 ; 2 ; 9 ; 15 ; 16 ; 17 ; 32]$. le postwar period . . ." However, Evans $[17,83]$ observes that, beginning in ... the Federal Reserve largely freed interest rates to seek their own levels . . "In evaluating is policy shift, most studies are in agreement with Barth [2, p. 38] that the shift in question $\mathrm{d}$ in fact increase interest rate volatility. For instance, Degen $[15,209]$ observes that "In order show its determination to halt inflation, the Federal Reserve committed itself to targeting the oney supply even if large fluctuations in interest rates would have to be tolerated." And Walsh 2,133 ] observes that "One expected result of such a policy shift was an increase in the ... latility of market interest rates, and this did occur." Indeed, Walsh [32, 133] goes on to add at "... the increase in interest rate fluctuations was very large, probably much larger than was
ticipated."

Before proceding, it is appropriate to note the observation by Abell $[1,67]$ that ". . . the deral Reserve in October, 1982 abandoned its non-borrowed reserves operating procedure in 'or of what was equivalent to an interest rate targeting procedure again." Moreover, this Octo$\therefore 1982$ Federal Reserve policy shift has been similarly characterized by others as well [19]. To lect the impact of such policy shifting (as well as other factors) on interest rate volatility during entire 1965-1989 period studied, we adopt the variable $V O L_{t}$. Using the 12 average monthly lds on new home mortgages in each year $t$ (FHLBB series), VOL $t$ is the variance of that yield
rear $t$. 
Next, we address the issue of S\&L capital requirements. It has been argued by Barth [2], Kaufman and Kormendi [25], and others that, as the regulators reduced the S\&L capital requirement over time, the thinning capital "cushion" exposed S\&Ls to a higher risk of failure. In other words, it is hypothesized here that, as a practical matter, we would expect that the S\&L failure rate would be a decreasing function of the $\mathrm{S} \& \mathrm{~L}$ capital requirement. To test this part of the model, section III uses the actual regulatory capital requirement at S\&Ls over the time period studied.

Finally, we note that a number of studies have argued that the Tax Reform Act of 1986 adversely impacted upon the real estate industry $[2 ; 7 ; 26 ; 29]$. Through a variety of provisions, dealing with such items as depreciation allowances, capital gains taxation, and limitations on the tax deductibility of losses on "passive" investments, this statute reduced the attractiveness of real estate purchases and ownership. All things considered, as Sanger, Sirmans, and Turnbull [29, 421] observe, "For the 1986 Tax Reform Act, the results indicate that the market assessed the changes to be detrimental to the owners of real estate assets." In turn, as argued by Barth [2], since the Tax Reform Act of 1986 was detrimental to the real estate industry, it also adversely impacted upon the profitability of and solvency of the S\&Ls. In the empirical estimates below, we adopt a dummy variable to capture the alleged effects of this tax statute on the S\&L crisis.

\section{Empirical Findings}

We begin our empirical analysis with the observation that there are at least two ways to measure the extent of S\&L failures: (1) the percentage of federally insured S\&Ls that failed over a given time period; and (2) the number of federally insured S\&Ls that failed over a given time period. Arguably, the former may be a superior measure of the $\mathrm{S} \& \mathrm{~L}$ problem since it provides a relative measure of the extent of the S\&L crisis. Nevertheless, in order to provide a broader perspective on the issue at hand, we provide empirical evidence on both of these measures of the S\&L crisis. Next, we also observe that the impact of many of the hypothesized causal variables on S\&L failures is unlikely to be instantaneous, suggesting that time lags must be built into the equations to be estimated.

Based upon the analysis provided in section II above, we initially estimate the following two reduced-form equations:

$$
\begin{aligned}
\text { PSL }_{t}= & a_{0}+a_{1} \text { RINS }_{t-2}+a_{2} \text { REC }_{t-2}+a_{3} R P_{t-2}+a_{4} \text { COST }_{t-1} \\
& +a_{5} \text { MORT }_{t}+a_{6} \text { VOL }_{t}+a_{7} \text { CAP }_{t-2}+a_{8} \text { TXR }_{t-2}+u_{1} \\
N S L t= & b_{0}+b_{1} \text { RINS }_{t-2}+b_{2} R E C_{t-2}+b_{3} R P_{t-2}+a_{4} \text { COST }_{t-1} \\
& +b_{5} \text { MORT }_{t}+b_{6} \text { VOL }_{t}+b_{7} \text { CAP }_{t-2}+b_{8} \text { TXR }_{t-2}+u_{2}
\end{aligned}
$$

where:

\footnotetext{
$P S L_{t}=$ the percentage of federally insured S\&Ls that failed in year $t$

$N S L_{t}=$ the number of federally insured $\mathrm{S} \& \mathrm{Ls}$ that failed in year $t$;

$a_{0}, b_{0}=$ constants;

$R_{I N S_{t-2}=}$ the FSLIC insurance ceiling per account on deposits at S\&Ls in year $t-2$, expressed in thousands of 1982 dollars $(1982=100.0)$;

$R E C_{t-2}=$ a dummy (binary) variable indicating whether the U.S. economy was in the 1981-1982 recession in year $t-2 ; R E C_{t-2}=1$ for such years and $R E C_{t-2}=$ 0 otherwise;
} 


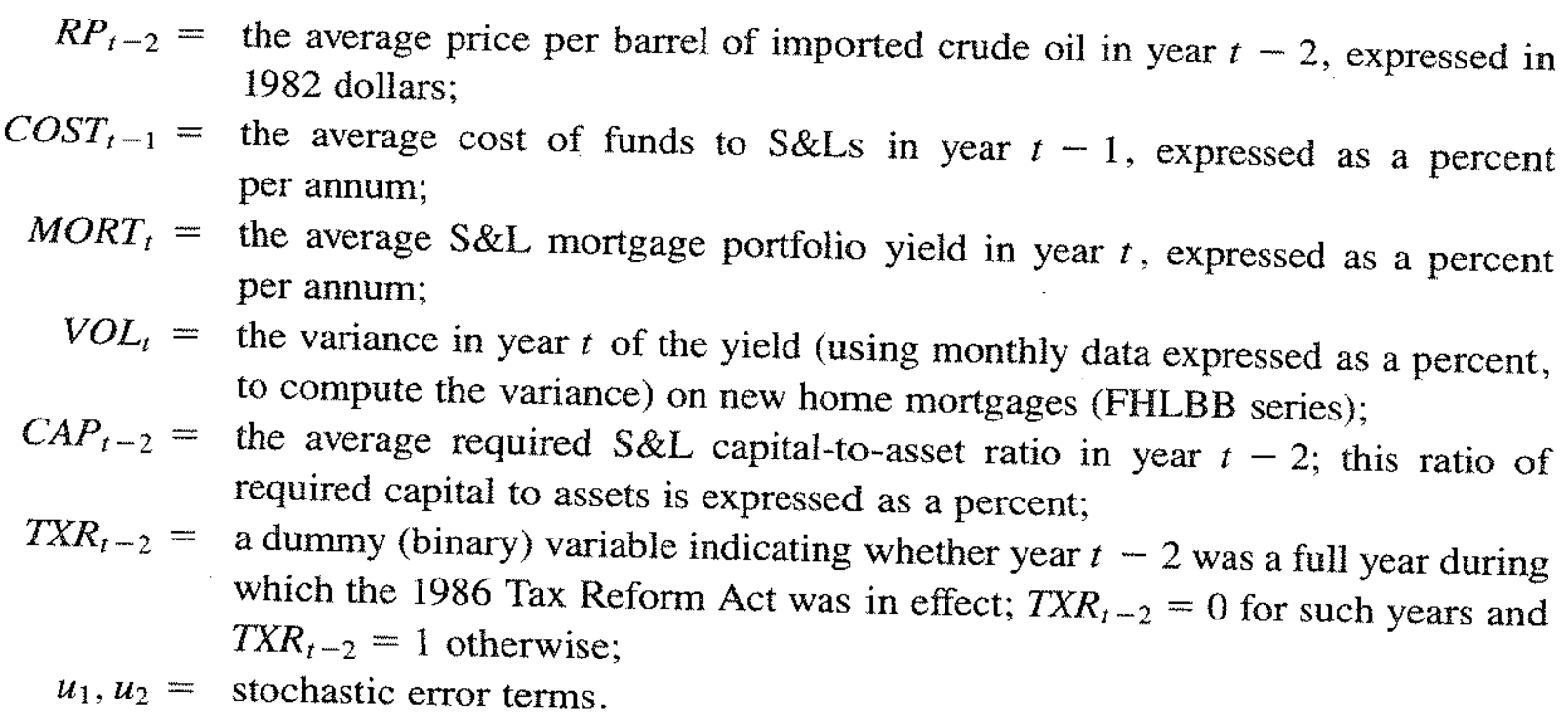

The data for variables $M O R T_{t}$ and $C O S T_{t-2}$ are unavailable for the years prior to 1965. Consequently, our empirical estimates are for the period 1965-1989.'

The data sources are, as follows: $P S L_{t}, N S L_{t}$, and $C A P_{t-2}$ are from Barth [3]; the current dollar price of imported crude oil is from the Statistical Abstract of the United States, various issues; MORT, COST $_{t-2}$, and the current dollar FSLIC deposit insurance ceiling per account are from the 1989 Savings \& Home Financing Source Book; the GNP deflator used to convert the current dollar price per barrel of imported crude petroleum into real terms (1982 dollars), $R P_{t-2}$, and to convert the FSLIC deposit insurance ceiling into real terms (1982 dollars), $R I N S_{t-2}$, was obtained from the Economic Report of the President, 1990; the data to compute $V O L_{t}$ were obtained from the Annual Statistical Digest of the Federal Reserve System.

Based upon the arguments summarized in section II above, we expect the following signs on the coefficients in equations (1) and (2):

$$
\begin{array}{llll}
a_{1}, b_{1}>0, & a_{2}, b_{2}>0, & a_{3}, b_{3}<0, & a_{4}, b_{4}>0 \\
a_{5}, b_{5}<0, & a_{6}, b_{6}>0, & a_{7}, b_{7}<0, & a_{8}, b_{8}<0 .
\end{array}
$$

Estimating equations (1) and (2) by OLS, using the Cochrane-Orcutt procedure to correct for first-order serial correlation, yields equations (3) and (4), respectively:

$$
\begin{aligned}
& P S L_{t}=33.47+0.08 \text { RINS }_{t-2}+2.53 R E C_{t-2}-0.57 R P_{t-2} \\
& \begin{array}{lll}
(+4.61) \quad(+3.18) & (-6.50)
\end{array} \\
& +1.81 \text { COST }_{t-1}-2.72 \text { MORT }_{t}+2.96 \text { VOL }_{t}-3.50 \text { CAP }_{t-2} \\
& \begin{array}{llll}
(+3.17) \quad(-4.87) & (+2.12) & (-6.54)
\end{array} \\
& -5.84 T X R_{t}-2, \quad D W=2.01, \quad \text { Rho }=-0.03, \quad R^{2}=0.90 \\
& (-5.76) \\
& N S L_{t}=987.7+2.33 \text { RINS }_{t-2}+71.86 \text { REC }_{t-2}-16.6 R P_{t-2} \\
& (+4.56) \quad(+3.04) \quad(-6.40) \\
& +54.6 \text { COST }_{t-1}-81.2 \text { MORT }_{t}+89.3 \text { VOL }_{t}-103.1 \text { CAP }_{t-2} \\
& \begin{array}{llll}
(+3.22) & (-4.85) & (+2.16) & (-6.42)
\end{array}
\end{aligned}
$$

1. However, estimates of $\mathrm{COST}_{t-2}$ are available for the years 1963 and 1964 and were in fact used in this study. 


$$
\begin{aligned}
& -174.2 T X R_{t-2}, \quad D W=1.96, \quad \text { Rho }=-0.01, \quad R^{2}=0.90 \\
& (-5.85)
\end{aligned}
$$

where terms in parentheses beneath coefficients are $t$-values.

As shown in equations (3) and (4), all 16 of the estimated coefficients exhibit the expected signs. In addition, 14 of the 16 estimated coefficients are statistically significant at the one percent level, and the remaining two are significant at the five percent level. The coefficient of determination in both estimates is 0.90 , so that the model explains roughly 90 percent of the variation in the dependent variables.

The results provided in equations (3) and (4) imply, among other things, that S\&L failures (whether measured by $P S L_{t}$ or $N S L_{t}$ ) are (as expected) an increasing function of $R E C_{t-2}$, $C O S T_{t-1}$, and $V O L_{t}$, whereas they are a decreasing function of $M O R T_{t}, R P_{t-2}, C A P_{t-2}$, and $T X R_{t-2}$. Perhaps most relevantly, in terms of the basic objective of this study, the evidence indicates that $\mathrm{S} \& \mathrm{~L}$ failures $\left(P S L_{t}\right.$ and $\left.N S L_{t}\right)$ are an increasing function of the real ceiling (per account) on federal deposit insurance. This finding strongly supports the aforementioned arguments by Barth [2], Barth and Bradley [4], Kane [23; 24], Jaffee [21], and White [33].

Moreover, this same basic conclusion is generated even if we substitute the current dollar value of the FSLIC insurance ceiling per account $\left(I N S_{t-2}\right.$, expressed in thousands of current dollars) for $R_{I N S_{t-2}}$ in equations (1) and (2). To illustrate, we now estimate equations (1) and (2), given this substitution; the OLS results, after having used the Cochrane-Orcutt procedure to correct for first-order serial correlation, are given by equations (5) and (6):

$$
\begin{aligned}
& P S L_{t}=14.37+0.085 I N S_{t-2}+2.34 R E C_{t-2}-0.44 R P_{t-2} \\
& (+6.92) \quad(+4.01) \quad(-6.43) \\
& +0.93 \mathrm{COST}_{t-1}-1.42 \mathrm{MORT}_{t}+2.26 \mathrm{VOL}_{t}-1.14 \mathrm{CAP}_{t-2} \\
& \begin{array}{llll}
(+1.97) \quad(-3.14) \quad(+2.37) \quad(-2.21)
\end{array} \\
& -4.54 T_{X R_{t-2}}, \quad D W=2.01, \quad \text { Rho }=-0.04, R^{2}=0.93 \text {; } \\
& (-5.91) \\
& N S L_{t}=432.6+2.53 I N S_{t-2}+67.6 R E C_{t-2}-12.71 R P_{t-2} \\
& (+7.04) \quad(+3.95) \quad(-6.41) \\
& +27.9 \mathrm{COST}_{t-1}-43.6 \mathrm{MORT}_{t}+72.3 \mathrm{VOL}_{t}-33.7 \mathrm{CAP}_{t-2} \\
& \begin{array}{llll}
(+1.99) \quad(-3.28) & (+2.59) \quad(-2.24)
\end{array} \\
& -136.0 T X R_{t-2}, \quad D W=2.00, \quad \text { Rho }=-0.04, R^{2}=0.93 \text {. } \\
& (-6.09)
\end{aligned}
$$

The results shown in equations (5) and (6) are entirely compatible with those in the estimated equations (3) and (4) above. Perhaps of greatest relevance, given the objective of this study, is the fact that $S \& L$ failures $\left(P S L_{t}\right.$ and $\left.N S L_{t}\right)$ are an increasing function of the federal deposit insurance ceiling per account. Based on equations (3), (4), (5), and (6), this finding apparently obtains whether that ceiling is expressed in real terms or in nominal terms.

It should be noted that a variety of alternative lag structures within the same basic model also yield the above conclusion. In addition, it should be noted that variations on the basic model yield the aforementioned conclusion as well. ${ }^{2}$ For example, consider the following variation on equations (1) and (2):

2. We have experimented with a number of different variables to reflect Regulation $Q$, which Ritter and Silber $[28,97]$ view as causing “. . f financial disintermediation during the tight money episodes of the 1960 s and 1970 s, and 


$$
\begin{aligned}
\text { PSL }_{t}= & c_{0}+c_{1} \text { RINS }_{t-2}+c_{2} V O L_{t}+c_{3} R P_{t-2}+c_{4} \text { COST }_{t-2} \\
& +c_{5} \text { MORT }_{t}+c_{6} \text { CAP }_{t-2}+u_{3} \\
N S L_{t}= & d_{0}+d_{1} \text { RINS }_{t-2}+d_{2} V_{O L_{t}}+d_{3} R P_{t-2}+d_{4} \text { COST }_{t-2} \\
& +d_{5} \text { MORT }_{t}+d_{6} \text { CAP }_{t-2}+u_{4}
\end{aligned}
$$

where:

$$
\begin{aligned}
& c_{0}, d_{0}=\text { constants; } \\
& u_{3}, u_{4}=\text { stochastic error terms. }
\end{aligned}
$$

Estimating the reduced-form equations (7) and (8) by OLS, using the Cochrane-Orcutt procedure to correct for first-order serial correlation, yields equations (9) and (10), respectively:

$$
\begin{aligned}
& P S L_{t}=16.99+0.07 R I N S_{t-2}+4.12 V_{O L}-0.31 R P_{t-2} \\
& \begin{array}{lll}
(+3.35) \quad(+2.87) \quad(-3.75)
\end{array} \\
& +1.32 \text { COST }_{t-2}-1.79 \text { MORT }_{t}-1.33 \text { CAP }_{t-2} \text {, } \\
& \begin{array}{lll}
(+2.64) & (-3.07) \quad(-2.80)
\end{array} \\
& D W=2.12, \quad \text { Rho }=-0.12, R^{2}=0.79 \\
& N S L_{t}=423.2+1.96 R_{I N S_{t-2}}+129.21 \text { VOL }_{t}-9.04 R P_{t-2} \\
& \begin{array}{lll}
(+3.36) \quad(+3.03) \quad(-3.68) & 0
\end{array} \\
& +39.85 \operatorname{COST}_{t-2}-54.67 \mathrm{MORT}_{t}-39.38 \mathrm{CAP}_{t-2} \text {, } \\
& \begin{array}{lll}
(+2.68) \quad(-3.15) \quad(-2.77)
\end{array} \\
& D W=2.11, \quad R h o=-0.11, R^{2}=0.78 \text {. }
\end{aligned}
$$

In estimates (9) and (10), all 12 of the estimated coefficients exhibit the expected signs and are significant at the two percent level or better. Indeed, ten of these estimated coefficients are significant at the one percent level. Of greatest relevance to the objectives of this paper are the signs and significance levels of the estimated coefficients on the variable $R I N S_{t-2}$. In both of these estimations, the coefficients on variable $R I N S_{t-2}$ are positive and statistically significant at the one percent level. These results are consistent with the earlier findings in this paper and imply, as Barth [2], Barth and Bradley [4], Kane [23; 24], and others have so vehemently argued, that the federal deposit insurance system has significantly contributed to the S\&L crisis. ${ }^{3}$

again in 1981." Others make similar arguments [11]. In the various estimates generated, we found no substantive support for the idea that Regulation $Q$ per se induced significant $S \& L$ failures.

3. One alternative formulation to equation (7) is illustrated by the OLS estimation below, where the CochraneOrcutt procedure was used (once again). In this case, the variables $C O S T_{t-2}$ and $M O R T_{t}$ in (7) are replaced by the ratio $\left(C O S T_{t-2} / M O R T_{t}\right)$, which is expressed as a percent per annum. The results are, as follows:

$$
\begin{aligned}
& P S L_{t}=-5.98+0.14\left(\text { COST }_{t-2} / \text { MORT }_{t}\right)+0.05 R I N S_{t-2}-0.57 C_{A} P_{t-2} \\
& (+2.59) \quad(+2.59) \quad(-1.94) \\
& +2.27 V O L_{t}-0.33 R P_{t-2}, \quad D W=1.99, \quad R h o=-0.09, \quad R^{2}=0.62 \text {. } \\
& (+1.99) \quad(-4.08)
\end{aligned}
$$

Yet again, federal deposit insurance is shown to raise the $S \& L$ failure rate $\left(P S L_{t}\right)$. The same conclusion can be shown to apply for $N S L_{t}$. 


\section{Conclusion}

Barth [2; 3], Barth and Bradley [4], Jaffee [21], Kane [23; 24], White [33], and others have argued that the federal deposit insurance system has adversely impacted upon the economic health of the S\&L industry. The empirical findings provided in this paper have generated strong empirical support for this argument. Correspondingly, our empirical findings are strong evidence of a need for a major reform of the existing system. The literature on reforming the federal deposit insurance system is well developed $[2 ; 4 ; 10 ; 14 ; 21 ; 22 ; 23 ; 33]$. On the basis of our findings, we would argue that at least one part of said reform would seem to be a limitation on the ceiling on federal deposit insurance per account or per depositor; perhaps even a cut in that celling would be beneficial. In any event, given the variety of sensible reforms that have been proposed in the literature, it clearly is time for meaningful action on federal deposit insurance reform!

\section{References}

1. Abell, John D., "The Role of the Budget Deficit during the Rise in the Dollar Exchange Rate from 1979-1985." Southern Economic Journal, July 1990; 66-74.

2. Barth, James R. The Great Savings and Loan Debate. Washington, D.C.: The AEI Press, 1991.

3. - "Statement before the House Committee on Banking, Finance, and Urban Affairs." 101st Congress, April 11, 1990.

4. ___ and Michael G. Bradley, "Thrift Deregulation and Federal Deposit Insurance." Journal of Financial Services Research, September 1989, 231-59. $79-95$.

5. — , George Iden, and Frank Russek, "Do Deficits Really Matter?" Contemporary Policy Issues, Fall 1984,

6. ㄴ , and ㄴ..... "Federal Borrowing and Short Term Interest Rates: Comment." Southern Economic Journal, October 1985, 554-59.

7. Boskin, Michael J., "Tax Policy and Economic Growth: Lessons from the 1980s." Journal of Economic Perspectives, Fall 1988, 71-97.

8. Bradley, Michael D. and Dennis W. Jansen, "Deposit Market Deregulation and Interest Rates." Southern Economic Journal, October 1986, 478-89.

9. Brocato, Joseph, "The October 1979 Federal Reserve Policy Shift: An Analysis Using Variance Decomposition." Atlantic Economic Journal, December 1986, 85-89.

10. Brumbaugh, Dan. Thrifts in Crisis. New York: Harper \& Row, 1988.

11. Cargill, Thomas F. and Gillian G. Garcia. Financial Reform in the 1980s. Stanford, Calif.: Hoover Institution Press, 1985.

12. Carron, Andrew S. The Plight of the Thrift Institutions. Washington, D.C.: The Brookings Institution, 1982.

13. Carson, Robert B. What Economists Know. New York: St. Martin's Press, 1990.

14. Cooper, Kerry and Donald R. Frase. Banking Deregulation and the New Competition in Financial Services. Cambridge, Mass.: Ballinger Publishing Company, 1984.

15. Degen, Robert A. The American Monetary System. Lexington, Mass.: Lexington Books, 1987.

16. Dutkowsky, Donald $H$. and H. Sonmez Atesoglu, "Interest Rate Volatility and Monetary Neutrality." Quarterly Review of Economics and Business, Summer 1990, 17-23. $68-87$

17. Evans, Paul, "Do Large Deficits Produce High Interest Rates?" American Economic Review, March 1985 ,

18. Friedman, Benjamin, "Lessons on Monetary Policy from the 1980s." Journal of Economic Perspectives, Summer $1988,51-72$.

19. Gilber, R. Alton, "Operating Procedures for Conducting Monetary Policy." Review, Federal Reserve Bank of St. Louis, February 1985, 13-21.

50 .

20. Horvitz, Paul M., "The FSLIC Crisis and the Southwest Plan." American Economic Review, May 1989, 146-

21. Jaffee, Dwight M., "Symposium on Federal Deposit Insurance for S\&L Institutions." Journal of Economic Perspectives, Fall 1989, 3-10.

22. Kane, Edward J. The Gathering Crisis in Federal Deposit Insurance. Cambridge, Mass.: MIT Press, 1985. 
23. "The High Cost of Incompletely Funding the FSLIC's Shortage of Explicit Capital." Journal of Economic Perspectives, Fall 1989, 31-47.

24. "S\&Ls and Interest-Rate Reregulation: The FSLIC as an In-place Bailout Program." Housing Finance Review, July $1982,219-43$.

25. Kaufman, George G. and Roger C. Kormendi. Deregulating Financial Services: Public Policy in Flux. Cambridge, Mass.: Ballinger Publishing Company, 1986. 11-28.

26. Pechman, Joseph A., "Tax Reform: Theory and Practice." Journal of Economic Perspectives, Summer 1987,

27. Rapping, Leonard A. and Lawrence B. Pulley, "Speculation, Deregulation, and the Interest Rate." American Economic Review, May 1985, 108-13.

28. Ritter, Lawrence S. and William L. Silber. Principles of Money, Banking and Financial Institutions, 6th ed. New York: Basic Books, 1989.

29. Sanger, Gary C., C. F. Sirmans, and Geoffrey K. Turnbull, "The Effects of Tax Reform on Real Estate: Some Empirical Results." Land Economics, November 1990, 409-24. 72.

30. Sider, Hal, "Unemployment Duration and Incidence: 1968-82." American Economic Review, June 1985, 461-

31. Tatom, John A., "Interest Rate Variability: Its Link to the Variability of Money Growth and Economic Performance." Review, Federal Reserve Bank of St. Louis, November 1984, 31-47.

32. Walsh, Carl E., "Interest Rate Volatility and Monetary Policy." Journal of Money, Credit and Banking, May $1984,133-50$.

33. White, Lawrence J., "The Reform of Federal Deposit Insurance." Journal of Economic Perspectives, Fall 1989, 11-29. 